\title{
Feeding dried distillers grains with solubles affects composition but not oxidative stability of milk
}

\author{
E. D. Testroet, ${ }^{*}$ G. Li,† D. C. Beitz, ${ }^{*}$ and S. Clark $\ddagger^{1}$ \\ *Department of Animal Science, lowa State University, Ames 50011 \\ †Wonton Food Inc., 220-222 Moore Street, Brooklyn, NY 11206 \\ ‡Department of Food Science and Human Nutrition, lowa State University, Ames 50011
}

\begin{abstract}
Feeding lactating dairy cows dried distillers grains with solubles (DDGS) increases the concentration of unsaturated fatty acids in the milk from those cows, potentially leading to increased susceptibility to development of off-flavors. Feeding DDGS has been loosely implicated to be a cause of development of spontaneous oxidative off-flavor in milk. We hypothesized that increased feeding of DDGS would accelerate development of off-flavors and that fortification with vitamin $\mathrm{E}(0.06 \% \mathrm{wt} / \mathrm{wt})$ or $\mathrm{C}(0.06 \% \mathrm{wt} / \mathrm{wt})$ would prevent spontaneous oxidative off-flavors. The objective of this research was to determine the effects of feeding DDGS to lactating dairy cows on several parameters of milk quality as determined by both chemical and sensory evaluations. Twenty-four healthy mid-lactation Holstein dairy cows were fed total mixed rations containing DDGS $(0,10$, or $25 \%$ dry matter). Cows were blocked by parity and randomly assigned to 1 of 2 groups (12 cows each). Each group received all 3 treatments in a 3-period Youden square design so that each cow served as her own control. Samples of milk from individual cows for proximate analysis and pooled milk for pasteurization and sensory analysis were collected on d 14, 21, and 28 of each experimental period. Pooled milk was assayed for peroxides and free fatty acids and evaluated by a trained sensory panel for the presence of 7 off-flavors common to milk on d 1, 3, and 7. Feeding $25 \%$ DDGS caused a significant decrease in daily milk yield. Increased dietary inclusion of DDGS also caused a concomitant decrease in percentage of milk fat and an increase in percentages of both solids nonfat and protein. Milk peroxides and free fatty acids were almost all below the detection limit, and the few exceptions were not found in replicated analyses. Sensory analysis revealed off-flavors only in milk from cows fed 0\% DDGS when that milk was stored for $7 \mathrm{~d}$ and when milk from cows fed $25 \%$ DDGS was fortified with $0.06 \%$ (wt/wt)
\end{abstract}

Received November 2, 2014.

Accepted January 9, 2015.

${ }^{1}$ Corresponding author: milkmade@iastate.edu vitamin C. Those few detected off-flavor scores were less than $1.5 \mathrm{~cm}$ on a $15-\mathrm{cm}$ line scale, indicating that the differences are not practically significant. Peroxide values support the findings by the sensory panel that both feeding DDGS at 10 and $25 \%$ and vitamin E and C fortification did not practically change the oxidative stability of milk. These results, taken together, indicate that feeding DDGS under our experimental conditions modified milk composition, but did not contribute to the development of off-flavors in milk.

Key words: oxidation, flavor, sensory, cow, milk fat depression

\section{INTRODUCTION}

In the early spring of 2009 and 2010, recurring consumer complaints about milk going bad in the Midwest drew the attention of farmers, processors, grocers, a major dairy cooperative, and educators. Experienced milk evaluators from those groups determined the primary off-flavor of the rejected milk to be oxidized. Raw milk, initially good, spontaneously became oxidized within 5 d of milk collection. Spontaneous oxidation (SO) has been classified as oxidation that spontaneously happens within $48 \mathrm{~h}$ of milking (Dunkley and Franke, 1967), and spontaneous oxidized flavor (SOF) refers to those flavors associated with SO. Investigations (i.e., grocery tours, plant tours, milk analyses, and feed analyses) led to the determination that $\mathrm{SO}$ and $\mathrm{SOF}$ originated from the cow rather than from other sources of oxidation (e.g., metal ions, light). Several factors have been implicated as the probable cause of SOF, but it is suspected that one primary source of SOF is from the diet of the cow (Government of Manitoba, Agriculture, Food and Rural Initiatives, 2008).

Previous studies have found that feeding dried distillers grains with solubles (DDGS), a co-product of ethanol production, to dairy cows increases unsaturated FA in milk (Schingoethe et al., 1999; Leonardi et al., 2005; Anderson et al., 2006). Because the corn oil in DDGS is typically more than $60 \%$ linoleic acid $\left(\mathrm{C}_{18: 2}\right)$, feeding it should be expected to contribute to an increase 
in unsaturated FA in milk (Schingoethe et al., 2009), despite the extensive biohydrogenation by rumen microbes (Jensen et al., 1991). Hence, it is reasonable to suspect that increased concentrations of unsaturated FA in milk could lead to the development of oxidation in milk from cows fed DDGS (Figure 1). In the current study, we investigated how feeding lactating dairy cows DDGS affects milk oxidative stability by testing milk with sensory and chemical tests. Much previous research has focused on the effect of feeding DDGS on production parameters (e.g., DMI, volatile ruminal short-chain FA, feed efficiency, milk production, milk and milk fat composition; Schingoethe et al., 1999; Anderson et al., 2006; Schingoethe et al., 2009), but information is lacking in regards to milk sensory quality or susceptibility to oxidation from milk produced by cows fed DDGS. To our knowledge, ours is the only study that evaluated the effect of feeding DDGS to lactating dairy cows on the milk quality as evaluated by a trained descriptive analysis panel as well as chemical analyses. We hypothesized that (1) greater DDGS inclusion in the ration of lactating dairy cows would contribute to the development of SOF in milk and that (2) vitamin $\mathrm{E}$ and $\mathrm{C}$ fortification of milk would limit development of SOF in milk.

\section{MATERIALS AND METHODS}

\section{Experimental Design, Milk Collection, and Processing}

All experimental protocols involving animal and human subjects were approved by the Iowa State University Institutional Animal Care and Use Committee and Institutional Review Board, respectively. Human subjects reviewed and signed an informed consent form before beginning the research. Animal protocols were additionally reviewed and approved by the Iowa State University Dairy Users Group before initiation. Two groups of 12 mid-lactation primiparous and multiparous Holstein dairy cows were fed diets containing 3 dietary concentrations of DDGS in a Youden square design. The 3 diets were formulated to be isoenergetic with 0, 10, and 25\% DDGS as dietary DM (Table 1). Group 1 received the 0,10, and 25\% DDGS diets in periods 1,2 , and 3 , respectively, whereas group 2 received 10, 25, and 0\% DDGS in periods 1,2 , and 3 , respectively. Thus, each cow received all 3 diets in different periods and served as her own control. The DDGS were produced from corn-based ethanol production by Lincolnway Energy LLC (Nevada, IA). To balance the energetic content of each diet the rations had to be altered considerably from the 0\% DDGS diet

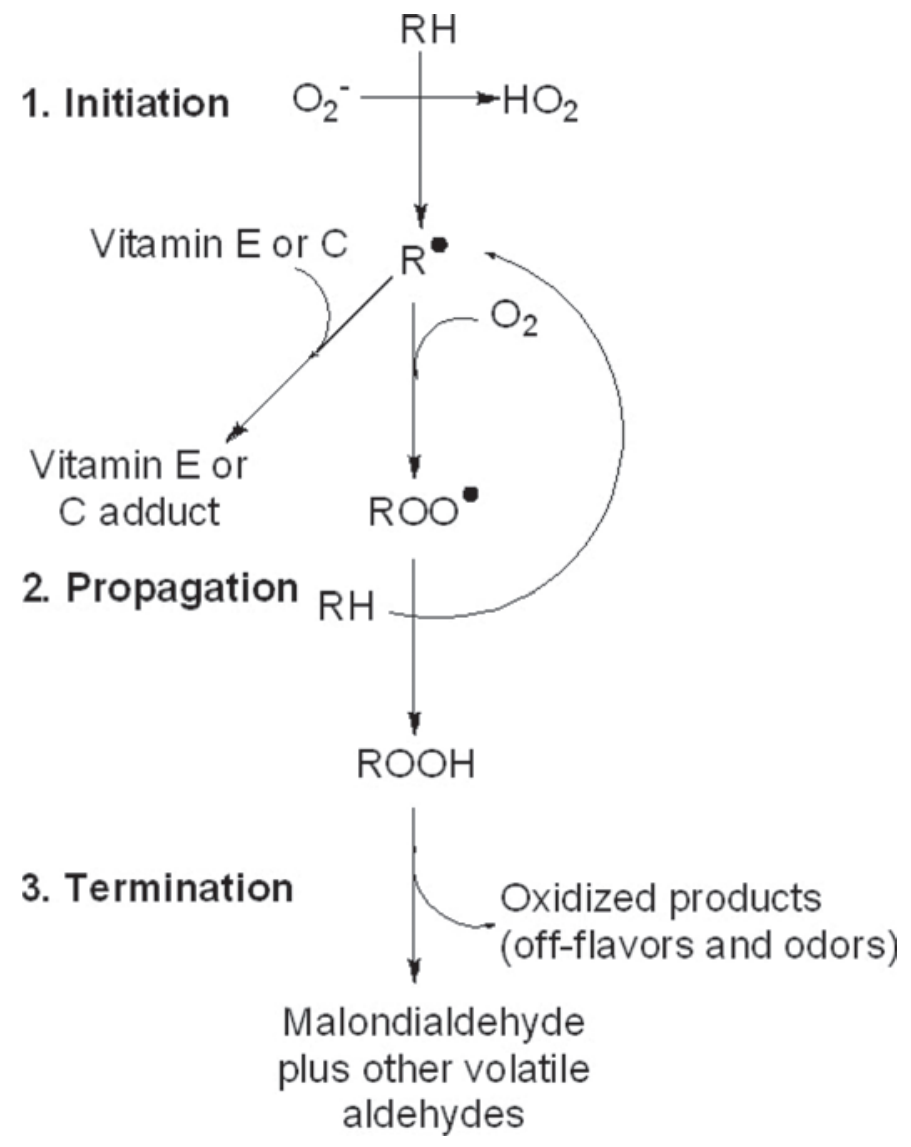

Figure 1. Illustration of oxidative off-flavor development and autoxidation of milk fat, where RH is an unsaturated fatty acid. Initiators of this chain reaction in milk include metals and UV light. Initiation of the reaction illustrated, followed by propagation of the reaction (2), and finally termination (3) of the chain reaction are described. The chain reaction will continue until the radical species is quenched by an antioxidant or by combination with another radical species.

to the 25\% DDGS diet. Although the compositions of the treatment diets vary, a no-DDGS diet was needed to ensure that these groups of cows did not produce milk that developed oxidized off-flavors on a typical lactation ration, thus allowing us to examine the effects of feeding DDGS. Nutritional compositions, as determined by near-infrared spectroscopy, of the rations and DDGS are presented in Table 2 (Dairyland Laboratories Inc., Arcadia, WI). Initially, cows were allowed to acclimate to the diet for $7 \mathrm{~d}$. For the remainder of the experiment, the cows transitioned directly to the next treatment with the first $14 \mathrm{~d}$ being excluded from sampling and analysis to minimize carry-over effects. Each experimental period lasted for $28 \mathrm{~d}$.

During each of 3 experimental periods, milk was collected from the morning milking 14, 21, and $28 \mathrm{~d}$ after the start of the period. On the same collection days, during the third milking of the day, milk was automatically 
Table 1. Ingredients of three treatment diets containing differing concentrations of dried distillers grains with solubles (DDGS) ${ }^{1}$

\begin{tabular}{lccc}
\hline & \multicolumn{3}{c}{ Treatment } \\
\cline { 2 - 4 } & $0 \%$ & $10 \%$ & $25 \%$ \\
Ingredient, \% of DM & DDGS & DDGS & DDGS \\
\hline Corn silage & 41.7 & 43.2 & 41.1 \\
Alfalfa hay & 13.1 & 13.9 & 13.2 \\
Soybean meal (47\%) & 12.3 & 6.1 & 1.7 \\
Cottonseed (whole) & 8.5 & 9.0 & 8.5 \\
Finely ground corn & 1.6 & 8.6 & 3.3 \\
DDGS & 0.0 & 10.8 & 24.3 \\
Lactation mix $^{2}$ & 22.6 & 8.4 & 8.0 \\
\hline
\end{tabular}

${ }^{1}$ All ingredients were mixed and fed as a TMR.

${ }^{2}$ Lactation mix ingredients as fed: $73.9 \%$ ground rolled corn; $4.5 \%$ Supercharger II (fat supplement; Origo, New Ulm, MN): $4.3 \%$ limestone; $3.6 \%$ blood meal; $3.2 \%$ sodium bicarbonate; $2.7 \%$ fine rock salt; $2.3 \%$ urea; $1.8 \%$ pork meat and bone meal; $1.2 \%$ monocalcium phosphate 21\%; $0.9 \%$ magnesium oxide; $0.7 \%$ Metasmart [methionine supplement (Adisseo USA Inc., Alpharetta, GA)]; 0.5\% Dynamate [vitamin and trace mineral premix (Consumer's Supply Distributing Company, Sioux City, IA)], ; 0.5\% Dairy Balancer II [vitamin and trace mineral premix (Nutritional Professionals Inc., Hortonville, WI)]; $0.04 \%$ Rumensin 90 .

sampled from each individual cow (Boumatic, Madison, WI) for proximate analysis, to represent one complete milking. On each collection day (first milking of the day), milk was collected from each treatment group

Table 2. Composition of dried distillers grains with solubles (DDGS) and TMR

\begin{tabular}{lcrrr}
\hline & & \multicolumn{3}{c}{ TMR $^{1}$} \\
\cline { 3 - 5 } Component & & & \\
\cline { 3 - 5 } & DDGS & $0 \%$ & $10 \%$ & $25 \%$ \\
\hline CP, \% & 29.5 & 17.8 & 16.9 & 18.5 \\
AD-ICP, \% of CP & NA & 6.7 & 7.0 & 6.5 \\
Protein soluble, \% of CP & 17.0 & 28.8 & 30.4 & 26.2 \\
Fat & 12.1 & 5.9 & 5.5 & 7.2 \\
aNDF, ${ }^{3} \%$ & 28.8 & 32.5 & 32.7 & 33.9 \\
Lignin, \% of NDF & & 10.4 & 10.5 & 10.0 \\
Starch, \% & NA & 24.8 & 24.7 & 19.7 \\
ND-ICP, ${ }^{4} \%$ of DM (est.) & 5.1 & 2.8 & 2.7 & 3.0 \\
Ash, \% & 4.6 & 6.5 & 6.9 & 6.4 \\
Calcium, \% & 0.1 & 0.8 & 0.6 & 0.6 \\
Manganese, mg/kg & NA & 48.0 & 36.5 & 33.0 \\
Zinc, mg/kg & NA & 79.5 & 59.5 & 72.5 \\
Copper, mg/kg & NA & 19.5 & 15.5 & 18.0 \\
Iron, mg/kg & NA & 241.5 & 212.0 & 207.0 \\
TDN (OARDC), ${ }^{5} \%$ & 85.8 & 73.1 & 72.3 & 73.4 \\
NFC, \% & NA & 39.0 & 39.0 & 34.9 \\
NE ${ }_{\mathrm{L}}$ (OARDC), ${ }^{5}$ Mcal/kg & 1.98 & 1.67 & 1.65 & 1.68 \\
\hline
\end{tabular}

${ }^{1}$ Expressed as a percentage of DM.

${ }^{2}$ Acid detergent-insoluble crude protein.

${ }^{3}$ Amylase-treated neutral detergent fiber.

${ }^{4}$ Neutral detergent-insoluble crude protein as an estimated percent of DM.

${ }^{5} \mathrm{~A}$ summative calculation based on an Ohio Agricultural Research and Development Center method (an approach for energy evaluation); NRC (2001). and pooled within each treatment group. The pooled milk then was divided for 3 fortification treatments: no fortification (control), $0.06 \%$ (wt/wt) vitamin $\mathrm{E}$ fortification (tocopherol acetate; Dairy House, Fenton, MO), and $0.06 \%$ (wt/wt) vitamin $\mathrm{C}$ fortification (L-ascorbic acid, crystalline $\geq 98 \%$; Jianshan Pharmaceutical Co., Ltd., Jiansu, China). Vitamins were aseptically added to the raw milk. All 6 of the milks (3 fortification milks from 2 groups) were continuously pasteurized by HTST at $74^{\circ} \mathrm{C}$ for $24 \mathrm{~s}$ with a UHT/HTST Lab Electric Model 25HV Hybrid pasteurizer (MicroThermics, Raleigh, $\mathrm{NC}$ ). Vitamin $\mathrm{C}$ has been shown to be stable in broccoli for at least 15 min at $90^{\circ} \mathrm{C}$ (Munyaka et al., 2010), and therefore should remain stable through the HTST pasteurization employed in this experiment. The pasteurized milks were collected in commercial translucent plastic gallon milk jugs purchased from Anderson Erickson Dairy (Des Moines, IA). All of the gallon milk samples were labeled with a unique random 3-digit identification code and put into black opaque plastic bags to block light during transportation and storage. Milks were analyzed for the sensory off-flavors described in Table 3 and analyzed chemically (described later) for oxidation products after 1,3 , and $7 \mathrm{~d}$ of storage at $3{ }^{\circ} \mathrm{C}$ without light exposure.

\section{Short-Chain VFA Analysis of Rumen Fluid}

Rumen fluid was collected before the start of the first experimental period as well as on d 24 of each experimental period via an esophageal tube. The collected fluid was strained through cheesecloth to remove particulate matter. Sampling took place after the morning milking and an average of $1 \mathrm{~h}$ after feeding. Rumen fluid was frozen at $-20^{\circ} \mathrm{C}$ until analysis. Rumen fluids were thawed and then analyzed using a Varian 3900 gas chromatograph (Varian Chromatography systems, Palo Alto, CA) equipped with a $30 \mathrm{~m} \times 0.25 \mathrm{~mm}$ i.d. DB-FFAP column (Agilent Technologies, Santa Clara, CA) as described by Drewnoski et al. (2014).

\section{Milk FA Composition}

Total lipids were extracted from individual milk samples $(5 \mathrm{~mL})$ as described by Lin et al. (1995), dried under $\mathrm{N}_{2}$ gas, and resuspended in $5 \mathrm{~mL}$ of chloroform (HPLC grade, Fisher Scientific, Fairlawn, NJ). Milk lipids in chloroform were stored frozen at $-20^{\circ} \mathrm{C}$ until analysis. Lipids in chloroform were dried under $\mathrm{N}_{2}$ gas, followed by the addition of $650 \mu \mathrm{L}$ of redistilled 1-butanol (ACS grade, Fisher Scientific) and $100 \mu \mathrm{L}$ of acetyl chloride $(<99 \%$ pure, Acros Organics, NJ) while vortexing. Samples were purged with $\mathrm{N}_{2}$ gas and heated 
Table 3. Descriptions and recipes ${ }^{1}$ for 7 off-flavors of milk evaluated by trained panelists

\begin{tabular}{|c|c|c|}
\hline Off-flavor & Descriptor & Recipes for creating a definite level anchor for a defect ${ }^{2}$ \\
\hline Cooked & Eggy, sulfur, custard & Organic ultrapasteurized whole milk from paperboard. \\
\hline Flat & $\begin{array}{l}\text { Watered down, thinner mouth feel, less dairy } \\
\text { fattiness }\end{array}$ & Low-fat $(1 \%)$ pasteurized milk from paperboard. \\
\hline Light oxidized & $\begin{array}{l}\text { Cardboard, pasty taste, mouth-drying sensation, } \\
\text { smells like wet brown paper towel }\end{array}$ & $\begin{array}{l}\text { Whole milk in translucent plastic exposed to at least } 30 \text { min of UV } \\
\text { or fluorescent light. }\end{array}$ \\
\hline Metal oxidized & $\begin{array}{l}\text { Copper penny aroma or flavor, tingling } \\
\text { sensation on tongue; some similar mouth-drying } \\
\text { characteristics as light oxidized }\end{array}$ & $\begin{array}{l}\text { Prepare } 0.25 \% \text { cupric sulfate solution with deionized water. Add } 1 / 4 \\
\text { teaspoon to } 1 \mathrm{~L} \text { of pasteurized whole milk from paperboard. Allow } \\
\text { to stand for } 90 \mathrm{~min} \text { before tasting. }\end{array}$ \\
\hline
\end{tabular}

${ }^{1}$ Modified from Costello and Clark (2009).

${ }^{2}$ Where $1 / 2$ teaspoon $=2 \mathrm{~mL} ; 1 / 2$ cup $=118 \mathrm{~mL} ; 1.5$ tablespoons $=19 \mathrm{~mL} ; 2$ teaspoons $=6 \mathrm{~mL} ;$ and $1 / 4$ teaspoon $=1 \mathrm{~mL}$.

on a heating block at $60^{\circ} \mathrm{C}$ for 30 min. Samples then were cooled to room temperature, and $5 \mathrm{~mL}$ of $4 \%$ (wt/ vol) $\mathrm{K}_{2} \mathrm{CO}_{3}$ and $1.5 \mathrm{~mL}$ (ACS grade, Fisher Scientific) of hexane (HPLC grade, Fisher Scientific) were added. Next, samples were centrifuged for $5 \mathrm{~min}$ at $1,380 \times g$ and $21^{\circ} \mathrm{C}$ (Centrific model 228, Fisher Scientific). Following centrifugation, the hexane layer was transferred to a new tube and washed with $5 \mathrm{~mL}$ of distilled $\mathrm{H}_{2} \mathrm{O}$ while vortexing. Samples then were recentrifuged and washed 3 additional times. Butyl esters were analyzed on a Hewlett-Packard 6890 (Avondale, PA) gas chromatograph equipped with a flame ionization detector, a 30-m Supelco 2330 fused silica capillary column with a $0.25 \mathrm{~mm}$ i.d., $0.2 \mu \mathrm{m}$ of film thickness (Supelco, Bellefonte, PA), and a 3396A integrator. The oven and injector of the chromatograph were held at $250^{\circ} \mathrm{C}$ with the column at an initial temperature of $50^{\circ} \mathrm{C}$ with a hold time of $1.44 \mathrm{~min}$, followed by a $5^{\circ} \mathrm{C}$ per minute ramp to $225^{\circ} \mathrm{C}$. Commercially available external standards were used to identify peaks by retention time (GLC-74 and GLC-79, Nu-Chek Prep, Elysian, MN). Pure $\mathrm{C}_{5: 0}$, $\mathrm{C}_{11: 0}$, and $\mathrm{C}_{19: 0}$ (Sigma-Aldrich, St. Louis, MO) were used as internal standards to calculate response factors. The FA $\mathrm{C}_{5: 0}$ was used to apply correction factors to $\mathrm{FA}$ concentrations of $\mathrm{C}_{4: 0} \mathrm{C}_{8: 0}, \mathrm{C}_{11: 0}$ for $\mathrm{C}_{10: 0} \mathrm{C}_{14: 0}$, and $\mathrm{C}_{19: 0}$ for $\mathrm{FA}$ longer than $\mathrm{C}_{14: 0}$.

\section{Milk Composition}

Individual milk samples ( 30 to $40 \mathrm{~mL}$ at $22 \pm 2^{\circ} \mathrm{C}$ ) were analyzed for percent fat, SNF, and protein content by using the LactiCheck-01 RapiRead Milk Analyzer (Page \& Pedersen Intl. Ltd., Hopkinton, MA). Fat, $\mathrm{SNF}$, and protein percentage were measured in duplicate.

\section{Sensory Evaluation-Descriptive Analysis}

Fourteen milk consumers over the age of 18, from Iowa State University, served as trained sensory panelists. Ten people were selected as the official panelists and 4 served as backup panelists for the study in case of absence. The panelists received a total of $8 \mathrm{~h}$ of training, which consisted of two 1-h training sessions per week over a 4 -wk period. Two additional 1-h review sessions were conducted between experimental periods. Seven common milk-related off-flavors (bitter, cooked, feed, flat, foreign, light-oxidized, and metal-oxidized) were chosen for sensory analysis. Panelists were taught both light and metal oxidized off-flavors because SOF is very similar to these 2 off-flavors. Attribute descriptions and training anchors are included in Table 3 . The panelists were trained to score the intensity of the offflavors on a $15-\mathrm{cm}$ line scale. A slight off-flavor score was considered a score around $3 \mathrm{~cm}$ on the $15-\mathrm{cm}$ line scale; a definite score was considered a score around 7.5 $\mathrm{cm}$; a pronounced score was considered a score near to $13 \mathrm{~cm}$.

During training, panelists were instructed to evaluate the milk with the following protocol: (1) pour milk samples into clean disposable $3-\mathrm{oz}$ plastic cups (Solo Cup Company, Lake Forest, IL) and fill about 1/4 to $1 / 3$ of the cup (about $30-45 \mathrm{~mL}$ of sample); (2) immediately cover the cup with one hand while holding the cup with the other hand to protect the milk sample from light and trap aromas inside the cup; (3) gently swirl the milk sample and use the heat of the hands to warm up the milk to release volatile compounds for about $5 \mathrm{~s}$; (4) take a deep sniff of the milk sample when removing the hand from the cup; and (5) take a generous sip of the milk, swirl it around the mouth, noting 
the flavors and sensations, and expectorate. Panelists were encouraged to breathe in fresh air through the mouth and then exhale through the nose to enhance the aromas in the sample retronasally. For the actual tasting sessions, the only difference in protocol was that panelists were seated in private booths and immediately prepoured samples were provided in 3-oz cups labeled with randomly generated 3 -digit numbers.

During training, pasteurized-homogenized fresh whole milk, in paperboard packaging (Anderson Erickson Dairy Inc., Des Moines, IA) from a local grocery store was presented to the panelists for representation of no defect milk. For the actual tasting sessions, the only difference involved inclusion of freshly delivered nonhomogenized whole milk (Hansen's Farm Fresh Dairy, Hudson, IA) as the no defect milk because the treatment milks also were not homogenized. Prior to serving, all gallon containers of milk were removed from the refrigerator, shielded from light, and left at room temperature for 30 min to take the chill off and enable mixing of cream layer. All gallon containers (1 package per treatment per day) were inverted at least 5 times before pouring of individual samples into 3 -oz cups for presentation to panelists.

Sensory evaluations of milk samples were conducted and recorded by using Compusense Five Release 5.4 (Compusense Inc., Guelph, ON, Canada) sensory software at the Nutrition and Wellness Research Center Sensory Evaluation Unit at Iowa State University 1, 3, and $7 \mathrm{~d}$ after pasteurization. Each panelist had an individual booth (lit with an incandescent bulb), laptop, and a unique registration code provided for evaluating milk samples. The computerized ballot had 15-cm line scales for each off-flavor. During the evaluation, panelists were provided with tap water and unsalted crackers as palate cleansers. Each panelist received samples for each evaluation session sequentially (9 in total), in a randomized order, and evaluated at his or her own pace. Panelists were not allowed to change the score once they had finished evaluating a sample.

\section{Peroxide Value and Free FA Content of Milk}

Oxidative stability of the milk was determined by measuring peroxide value (PV). Free fatty acid content was measured to indirectly evaluate milk for bacterial contamination. Peroxide and FFA contents were measured by using the SafTest system (MP Biomedicals, Solon, $\mathrm{OH}$ ) with the PeroxySafe STD kit and FaSafe STD kit (MP Biomedicals); milk from the same source as those samples evaluated by the sensory panel were used for SafTest analyses. Milk analyses were conducted following the PeroxySafe STD kit protocol and FaSafe
STD kit protocol (MP Biomedicals). Peroxide value and FFA concentration were assayed in duplicate.

\section{Statistical Analysis}

Twenty-four cows assigned to 2 groups of 12 cows each were used in our study; however, only 19 cows completed all 3 treatment periods because 5 were removed for illness (e.g., mastitis). Thus, only 19 cows were included in the final data analysis. The experimental design was a Youden square. Groups were blocked by parity and DIM was made to be approximately equal. All data analysis was performed in SAS 9.3 (SAS Institute Inc., Cary, NC).

Fat, SNF, and protein percent of the milk from all 3 dietary treatments were analyzed by using a one-way ANOVA. Sensory data analysis of the mean scores of each flavor attribute from 10 panelists (18 observations per treatment) was performed by using a MIXED model with 5 fixed effects (dietary treatment, collection day, fortification, storage day, experiment period, treatment $\times$ storage day, and treatment $\times$ fortification) and a random effect of group nested within period.

Milk yield and FA composition data were analyzed by using a MIXED model with repeated measures. For the milk yield analysis, the fixed effects were treatment and parity, the covariate was DIM, group was included as a random effect to account for treatment sequence and pen variation, and the repeated statement included the subject cow nested within treatment $\times$ period. Data for volatile ruminal short-chain fatty acids (SCFA) were analyzed by using a MIXED model that included the fixed effects parity and treatment and the covariate DIM as well as the random effects of cow nested within period and group. All means were separated by the least squares means (LSMEANS) command of SAS with a Tukey-Kramer multiple pairwise comparison adjustment, and statistical significance was declared at $P<0.05$.

\section{RESULTS AND DISCUSSION}

\section{Milk Composition}

Milk composition was analyzed 9 times for each individual cow in the study. Results are presented as the grand mean from the 9 analyses of fat, protein, and SNF percentage for all cows over the 3 collection days for each dietary treatment within a period (Table 4). Milk protein and SNF concentrations increased concomitantly $(P<0.05)$ with increased dietary inclusion of DDGS. Differences in milk protein percentage between control (no DDGS) and DDGS-fed cows are 
Table 4. Composition and yield of milk from cows fed 0, 10, and $25 \%$ dried distillers grains with solubles (DDGS) supplemented as a TMR ${ }^{1}$

\begin{tabular}{|c|c|c|c|c|}
\hline \multirow[b]{2}{*}{ Item } & \multicolumn{3}{|c|}{ Treatment $^{2}$} & \multirow[b]{2}{*}{$P$-value } \\
\hline & $0 \%$ DDGS & $10 \%$ DDGS & $25 \%$ DDGS & \\
\hline Fat, $\%$ & $3.17 \pm 0.10^{\mathrm{c}}$ & $2.89 \pm 0.10^{\mathrm{b}}$ & $2.60 \pm 0.09^{\mathrm{a}}$ & $<0.0001$ \\
\hline Protein, \% & $3.71 \pm 0.03^{\mathrm{a}}$ & $3.77 \pm 0.02^{\mathrm{b}}$ & $3.83 \pm 0.02^{\mathrm{c}}$ & $<0.0001$ \\
\hline SNF, $\%$ & $9.90 \pm 0.07^{\mathrm{a}}$ & $10.02 \pm 0.06^{\mathrm{b}}$ & $10.19 \pm 0.06^{\mathrm{c}}$ & $<0.0001$ \\
\hline Yield, kg/d & $33.40 \pm 1.37^{\mathrm{b}}$ & $32.90 \pm 1.38^{\mathrm{b}}$ & $30.62 \pm 1.38^{\mathrm{a}}$ & $<0.0001$ \\
\hline
\end{tabular}

not always observed (Nichols et al., 1998; Leonardi et al., 2005; Anderson et al., 2006; Janicek et al., 2008). Powers et al. (1995) observed that milk protein concentration and SNF increased when cows were fed highquality DDGS, and, consequently, it was suggested that decreased milk protein content and SNF from cows fed DDGS could be an indicator of poor-quality DDGS. The results and speculation by Powers et al. (1995) could explain why we found a concomitant increase in milk SNF and protein when dietary DDGS inclusion was increased when others did not, though it is difficult to test this explanation because good quality is defined poorly.

Milk fat concentration of the control diet milk (3.17\%) was greater than that of the 10\% DDGS diet milk $(2.89 \% ; P=0.0275)$, and feeding $25 \%$ DDGS caused even further milk fat depression $(2.60 \% ; P<$ 0.0109) (Table 4). The DDGS have about $11 \%$ lipid content on a DM basis (Hoffman and Baker, 2010) and are considered a good source of energy for dairy cows (Schingoethe et al., 2009). The primary purpose of feeding fats and oils to dairy cows is to provide higher energy intake to increase milk yield; however, dietary lipid supplements also could affect the concentration of milk fat and the FA composition in milk (Sutton, 1989), as well as inhibit fiber digestion (Ikwuegbu and Sutton, 1982). Typically, dairy nutritionists advise limited dietary inclusion of DDGS $(<20 \%$; Anderson et al., 2006) because the increased feeding of unsaturated dietary FA could cause milk fat depression. Indeed, the present study confirmed this response.

The decrease in fat content has been attributed to the effect of dietary lipids on ruminal fermentation (Zinn, 1989), the suppression of de novo synthesis of FA in the mammary gland (Offer et al., 1999), and insufficient forage fiber in the diet (Kalscheur et al., 2012). One possible reason for the observed milk fat depression in milk from cows fed DDGS is a result from incomplete biohydrogenation of $\mathrm{C}_{18: 2}$, resulting in production of a conjugated linoleic acid $\left(\mathrm{C}_{18: 2}\right.$ trans- 10,cis-12) that inhibits de novo milk fat synthesis in the mammary gland (Baumgard et al., 2001). A study by Leonardi et al. (2005) found milk fat concentration was decreased significantly by the dietary inclusions of up to $15 \%$ DDGS. In contrast, Anderson et al. (2006) found no differences in milk fat concentrations among all diets $(0,10$, and $20 \%$ DDGS), but they did observe a tendency for increased feeding of DDGS to lactating dairy cows to decrease milk fat content. Similar results were found by Sasikala-Appukuttan et al. (2008). A meta-analysis done by Kalscheur (2012) observed that milk fat depression only occurred when cows were fed DDGS in rations that contained less than $22 \%$ forage NDF and $50 \%$ total forage. Our diets contained more than $32 \% \mathrm{NDF}$ and more than $54 \%$ forage, indicating that percentage forage and NDF are not enough to explain the conflicting observations of the relationship of the feeding of DDGS and milk fat depression. A second possible reason for milk fat depression in cows fed DDGS has been speculated to result from the low amount of effective fiber in DDGS, meaning the particles are small and therefore are not as effective of a forage source as the forage that the DDGS replace (Kalscheur et al., 2012).

Milk fat percentage from cows fed the control diet was lower than expected for Holsteins that usually produce milk with approximately $3.5 \%$ fat (Walstra and Jenness, 1984). Heat stress may have caused some milk fat depression (Sasikala-Appukuttan et al., 2008) because the current study was conducted from July (midsummer) through October (early fall).

\section{Ruminal SCFA}

In the present study, we found no differences in the concentrations of the SCFA except for concentrations of butyrate and isovalerate (Table 5). Variability in the measured concentrations of SCFA and a lack of consistent trend, however, indicate that the few differences are not related to treatment. Our results are 
Table 5. Ruminal SCFA from lactating dairy cows fed 0, 10, and 25\% dried distillers grains with solubles (DDGS) as a total mixed ration ${ }^{1}$

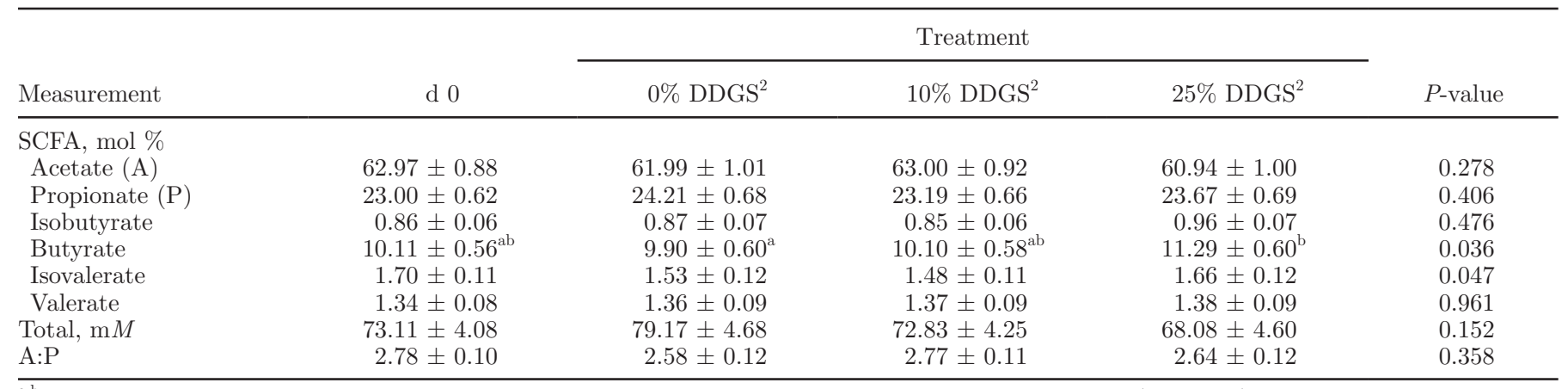

${ }_{\mathrm{a}, \mathrm{b}}$ Means within a row with different superscripts differ after Tukey HSD multiple comparisons analysis $(P<0.05)$.

${ }^{1}$ Least squares means \pm SEM.

${ }^{2}$ Expressed as a percentage of DM.

consistent with other studies that found feeding DDGS influenced ruminal isovalerate and valerate with no apparent trend emerging (Kleinschmit et al., 2007). In another study, feeding both wet and dried distillers grains with solubles only caused changes in isovalerate concentrations (Anderson et al., 2006). On the basis of our research and research by others, DDGS do not seem to affect ruminal SCFA concentrations in a meaningful way, and, importantly, DDGS do not affect acetate-topropionate ratios.

\section{Milk FA Profile}

Feeding lactating dairy cows the 25\% DDGS diet significantly increased $(P<0.05)$ stearic $\left(\mathrm{C}_{18: 0}\right)$, oleic $\left(\mathrm{C}_{18: 1}\right)$, and linoleic $\left(\mathrm{C}_{18: 2}\right)$ concentrations in milk (Table 6). These results were to be expected because they have been reported in many studies (Schingoethe et al., 1999; Leonardi et al., 2005; Anderson et al., 2006; Sasikala-Appukuttan et al., 2008). The reason that feeding DDGS increases unsaturated FA content in milk is because corn oil contains greater than $60 \%$ $\mathrm{C}_{18: 2}$, some of which escapes the rumen without any biohydrogenation or with incomplete biohydrogenation, thereby contributing to increases in the unsaturated FA found in the milk (particularly $\mathrm{C}_{18: 1}$ and $\mathrm{C}_{18: 2}$ ). Concentrations of no other FA in milk were affected by feeding DDGS $(P>0.05)$.

\section{Sensory Evaluation}

We hypothesized that fortification of milk with antioxidants such as vitamin $\mathrm{E}$ or $\mathrm{C}$ is a potential way to limit development of SOF (Figure 1). Sensory properties of nonfortified (control) milk did not differ from milk fortified with tocopherol $(P>0.4$; Table 7$)$. In this experiment, however, vitamin $\mathrm{C}$ fortification resulted in the greatest metal-oxidized off-flavor score of all milks when cows were fed dietary rations containing $25 \%$ DDGS. In all other cases, antioxidant fortification had no effect on off-flavors detected by the sensory panel. As with other differences in off-flavors, all mean scores were low, suggesting no practical effect of antioxidant fortification upon milk flavor for up to $7 \mathrm{~d}$ of storage without exposure to light.

Vitamin C fortification unexpectedly seemed to decrease the oxidative stability (on the basis of metaloxidized off-flavors) of milk enough that trained panelists could notice. Under certain conditions, vitamin $\mathrm{C}$ can act as a pro-oxidant by regenerating the perferryl radical at the initiation step of lipid oxidation (Lindmark-Månsson and Åkesson, 2000). Haase and Dunkley (1969) reported that vitamin C has prooxidant properties because it is able to catalyze the oxidation of linoleic acid (Haase and Dunkley, 1969) and can convert metal ions (e.g., iron, copper, and manganese) to a more reactive ionic form. However, it was reported that abomasal infusion of iron and copper salts had no effect on the concentration of iron and copper ions in milk and did not result in differences in off-flavors detected by a trained sensory panel (Mann et al., 2013). Moreover, the 25\% DDGS diet actually contained the lowest concentration of iron, with other pro-oxidant metals having an inconsistent trend (Table 2 ). However, because a principal role of vitamin $\mathrm{C}$ is to keep the metal core of metalloproteins (e.g., oxidases) in the reduced state, and because milk from cows fed $25 \%$ DDGS had the highest protein content, it is possible that oxidases that survive pasteurization and can produce hydrogen peroxide (e.g., xanthine oxidase; Claeys et al., 2013) were in greater concentration in milk from cows fed 25\% DDGS and were the mechanism through which vitamin $\mathrm{C}$ acted as a pro-oxidant when fortified in combination with milk from cows fed 
Table 6. Fatty acid composition ${ }^{1}$ of milk from cows fed dried distillers grains with solubles (DDGS)

\begin{tabular}{|c|c|c|c|c|}
\hline \multirow[b]{2}{*}{$\mathrm{FA}$, wt $\%$} & \multicolumn{3}{|c|}{ Treatment $^{2}$} & \multirow[b]{2}{*}{$P$-value } \\
\hline & $0 \%$ DDGS & $10 \%$ DDGS & $25 \%$ DDGS & \\
\hline $\mathrm{C}_{4: 0}$ & $1.10 \pm 0.16$ & $1.16 \pm 0.16$ & $1.04 \pm 0.17$ & 0.848 \\
\hline $\mathrm{C}_{6: 0}$ & $0.45 \pm 0.08$ & $0.33 \pm 0.08$ & $0.45 \pm 0.08$ & 0.479 \\
\hline $\mathrm{C}_{8: 0}$ & $0.80 \pm 0.11$ & $0.72 \pm 0.11$ & $0.71 \pm 0.11$ & 0.719 \\
\hline $\mathrm{C}_{10: 0}$ & $2.59 \pm 0.32$ & $2.00 \pm 0.33$ & $2.13 \pm 0.34$ & 0.389 \\
\hline $\mathrm{C}_{12: 0}$ & $3.33 \pm 0.42$ & $2.33 \pm 0.43$ & $2.63 \pm 0.44$ & 0.217 \\
\hline $\mathrm{C}_{14: 0}$ & $10.79 \pm 0.94$ & $8.73 \pm 0.97$ & $9.05 \pm 0.99$ & 0.248 \\
\hline $\mathrm{C}_{14: 1}$ & $2.33 \pm 0.48$ & $1.28 \pm 0.50$ & $1.75 \pm 0.51$ & 0.299 \\
\hline $\mathrm{C}_{15.0}$ & $1.64 \pm 0.30$ & $0.89 \pm 0.31$ & $1.20 \pm 0.31$ & 0.101 \\
\hline $\mathrm{C}_{15: 1}$ & $0.75 \pm 0.29$ & $0.73 \pm 0.30$ & $0.23 \pm 0.31$ & 0.430 \\
\hline $\mathrm{C}_{16: 0}$ & $27.70 \pm 1.03$ & $26.45 \pm 1.06$ & $25.58 \pm 1.09$ & 0.374 \\
\hline $\mathrm{C}_{16: 1}$ & $1.66 \pm 0.51$ & $1.70 \pm 0.52$ & $2.14 \pm 0.52$ & 0.598 \\
\hline $\mathrm{C}_{17: 0}$ & $1.11 \pm 0.40$ & $0.33 \pm 0.41$ & $0.76 \pm 0.42$ & 0.375 \\
\hline $\mathrm{C}_{17: 1}$ & $0.40 \pm 0.18$ & $0.63 \pm 0.18$ & $0.36 \pm 0.19$ & 0.537 \\
\hline $\mathrm{C}_{18: 0}$ & $12.17 \pm 0.56^{\mathrm{a}}$ & $14.00 \pm 0.57^{\mathrm{ab}}$ & $14.27 \pm 0.59^{\mathrm{b}}$ & 0.019 \\
\hline $\mathrm{C}_{18: 1}$ & $28.56 \pm 1.42^{\mathrm{a}}$ & $33.52 \pm 1.46^{\mathrm{b}}$ & $34.37 \pm 1.51^{\mathrm{b}}$ & 0.010 \\
\hline $\mathrm{C}_{18: 2}$ & $2.87 \pm 0.15^{\mathrm{a}}$ & $3.45 \pm 0.16^{\mathrm{b}}$ & $3.52 \pm 0.16^{\mathrm{b}}$ & 0.006 \\
\hline $\mathrm{C}_{18: 3}+\mathrm{C}_{20: 0}$ & $1.38 \pm 0.10$ & $1.52 \pm 0.10$ & $1.50 \pm 0.10$ & 0.518 \\
\hline $\mathrm{C}_{22: 0}$ & $0.40 \pm 0.05$ & $0.37 \pm 0.05$ & $0.35 \pm 0.05$ & 0.819 \\
\hline
\end{tabular}

${ }_{\mathrm{a}, \mathrm{b}}$ Means within a row with different superscripts differ $(P<0.05)$.

${ }^{1}$ Least squares means \pm SEM.

${ }^{2}$ Expressed as a percentage of DM.

25\% DDGS. Additionally, xanthine oxidase activity has been shown to be preserved by feeding supplemental vitamins $\mathrm{C}$ and $\mathrm{E}$ in combination with L-arginine to broiler chickens (Bautista-Ortega et al., 2014), providing further evidence that xanthine oxidase, in combination with vitamin $\mathrm{C}$, could promote the development of off-flavors.

Additionally, van Aardt et al. (2005) reported that vitamin $\mathrm{C}$ fortification in milk at a concentration of $0.05 \%$ can have a negative sensory effect on milk flavor. Kim et al. (2012) reported that vitamin $\mathrm{C}$ showed pro-oxidant properties at $0.02 \%$ (wt/vol) concentra- tion in oil-in-water emulsions, such as milk, whereas tocopherol had strong antioxidant capacity. Additionally, Barrefors et al. (1995) observed higher $\mathrm{C}_{18: 2}$ and $\mathrm{C}_{18: 3}$ contents, lower tocopherol contents, and higher vitamin $\mathrm{C}$ content in milk with SOF (Barrefors et al., 1995). Increased tocopherol content can improve the resistance of milk fat to oxidation (Nicholson and StLaurent, 1991; Charmley and Nicholson, 1993; Focant et al., 1998). Other studies, however, reported that increasing tocopherol concentration in milk by fortification was ineffective in controlling oxidized flavor in milk (Charmley and Nicholson, 1994; Van Aardt et al.,

Table 7. Mean sensory scores ${ }^{1}$ of milk from cows fed 0,10 , and $25 \%$ dried distillers grains with solubles (DDGS) and fortified with vitamin (Vit) E or vitamin C

\begin{tabular}{|c|c|c|c|c|c|c|c|c|c|c|c|}
\hline \multirow[b]{3}{*}{ Flavor } & \multicolumn{9}{|c|}{ Treatment $^{2}$} & \multirow[b]{3}{*}{ SEM } & \multirow{3}{*}{$\begin{array}{c}P \text {-value } \\
\begin{array}{l}\text { Treatment } \times \\
\text { Fortification }\end{array}\end{array}$} \\
\hline & \multicolumn{3}{|c|}{$0 \%$ DDGS } & \multicolumn{3}{|c|}{$10 \%$ DDGS } & \multicolumn{3}{|c|}{$25 \%$ DDGS } & & \\
\hline & None & Vit E & Vit $\mathrm{C}$ & None & Vit E & Vit $\mathrm{C}$ & None & Vit E & Vit $\mathrm{C}$ & & \\
\hline Bitter, cm & 0.13 & 0.31 & 0.16 & 0.15 & 0.15 & 0.19 & 0.08 & 0.08 & 0.14 & 0.06 & 0.304 \\
\hline Cooked, cm & 0.69 & 0.38 & 0.53 & 0.53 & 0.41 & 0.50 & 0.42 & 0.51 & 0.42 & 0.10 & 0.335 \\
\hline Feed, cm & 0.25 & 0.27 & 0.28 & 0.24 & 0.24 & 0.22 & 0.24 & 0.30 & 0.26 & 0.06 & 0.976 \\
\hline Flat, cm & 0.41 & 0.66 & 0.44 & 0.67 & 0.80 & 0.54 & 0.78 & 0.70 & 0.36 & 0.11 & 0.240 \\
\hline Foreign, cm & 0.55 & 0.98 & 1.01 & 0.94 & 1.08 & 0.90 & 0.97 & 0.73 & 1.14 & 0.22 & 0.052 \\
\hline Light-oxidized, cm & 0.72 & 0.75 & 0.90 & 0.84 & 0.57 & 0.93 & 0.65 & 0.61 & 0.95 & 0.11 & 0.547 \\
\hline Metal-oxidized, cm & 0.27 & 0.54 & 0.67 & 0.44 & 0.49 & 0.65 & $0.51^{\mathrm{a}}$ & $0.45^{\mathrm{a}}$ & $1.40^{\mathrm{b}}$ & 0.11 & 0.001 \\
\hline
\end{tabular}

${ }^{\mathrm{a}, \mathrm{b}}$ Means within a treatment and row with different superscripts differ $(P<0.05)$.

${ }^{1}$ Obtained from panelist ratings on 15 -cm line scales.

${ }^{2}$ Expressed as a percentage of DM. Vitamin E and C fortification at $0.06 \%$ wt/wt. 
Table 8. Mean sensory scores ${ }^{1}$ of milk from cows fed 0,10 , and $25 \%$ dried distillers grains with solubles (DDGS) and stored for 1,3 , and $7 \mathrm{~d}$

\begin{tabular}{|c|c|c|c|c|c|c|c|c|c|c|c|}
\hline Flavor & \multicolumn{9}{|c|}{ Treatment $^{2}$} & SEM & $P$-value \\
\hline Bitter, cm & $0.12^{\mathrm{b}}$ & $0.10^{\mathrm{ab}}$ & $0.38^{\mathrm{b}}$ & 0.18 & 0.19 & 0.13 & 0.08 & 0.08 & 0.12 & 0.06 & 0.032 \\
\hline Cooked, cm & $0.80^{\mathrm{b}}$ & $0.45^{\mathrm{ab}}$ & $0.36^{\mathrm{a}}$ & 0.51 & 0.55 & 0.39 & 0.34 & 0.51 & 0.50 & 0.10 & 0.017 \\
\hline Feed, cm & 0.26 & 0.30 & 0.24 & 0.31 & 0.16 & 0.24 & 0.28 & 0.18 & 0.33 & 0.06 & 0.247 \\
\hline Light-oxidized, cm & 0.64 & 0.88 & 0.84 & 0.77 & 0.83 & 0.73 & 0.77 & 0.64 & 0.80 & 0.11 & 0.367 \\
\hline Metal-oxidized, cm & 0.66 & 0.35 & 0.47 & 0.50 & 0.56 & 0.51 & 0.91 & 0.71 & 0.74 & 0.12 & 0.608 \\
\hline
\end{tabular}

${ }_{\mathrm{a}, \mathrm{b}}$ Means within a treatment and row with different superscripts differ $(P<0.05)$.

${ }^{1}$ Obtained from panelist ratings on 15 -cm line scales.

${ }^{2}$ Expressed as a percentage of DM.

2005). The conflicting results would suggest that antioxidant fortification to prevent development of SOF is not as simple as it would seem, possibly owing to other factors in the milk composition or processing.

Bitter and cooked off-flavors were the only off-flavors significantly affected by storage time, and those flavor defects were only detected in milk from cows that were fed the control diet (Table 8). Still, low mean scores limit the practical significance of the findings. Spontaneous oxidation was expected to manifest within $7 \mathrm{~d}$ of storage (Timmons et al., 2001), which is why milk quality was not evaluated beyond d 7 . These findings imply that these milk samples had sufficiently low-intensity off-flavor scores that they would likely be of little concern to most consumers for at least $7 \mathrm{~d}$. This milk was handled with great care to avoid exposure to light, and a fresh jug was opened on each day of sensory analysis.

Although significantly higher off-flavor scores were noted for milk from the $25 \%$ DDGS diet when milk was fortified with vitamin C (metal oxidized) and on d 7 of storage for milk from cows fed the control diet (bitter), all of the off-flavor sensory scores were lower than 1.5 on a $15-\mathrm{cm}$ line scale. Thus, practically speaking, no real apparent oxidized off-flavors were detected in any of the milk samples and DDGS did not contribute to a decrease in milk oxidative stability (Tables 7 and 8).

\section{PV and FFA Content}

The PV for all milk samples were lower than $0.5 \mathrm{mEq}$ of peroxides $/ \mathrm{kg}$ (data not shown), which was lower than the $0.7 \mathrm{mEq} / \mathrm{kg}$ of $\mathrm{PV}$ reported in a previous study (Let et al., 2005) for nonoxidized milk. Low amounts of FFA were detected (less than $1.05 \%$ oleic acid, data not shown) in several milk samples from the first period, but those results were not reproduced in the second and third period milks because all were below the detection limits. Strong correlations between concentrations of one of the main lipid oxidation products (lipid hydroperoxides) and the oxidized flavor in sensory analyses have been reported (Hedegaard et al., 2006). In the current study, the chemical analysis results support the sensory evaluation; no primary lipid oxidation products (i.e., peroxides) were detected by quantification of PV, likely because sensory analysis is able to distinguish small differences in oxidized flavor in milk undetectable by chemical analysis of PV (Let et al., 2005). Because we did not detect peroxides in any of the milk samples, 1 of 2 explanations are possible: no lipid oxidation occurred or all the peroxides formed had decomposed into secondary lipid oxidation products (e.g., aldehydes and ketones). If the second scenario were true, the sensory panel would have detected much higher oxidized offflavors in the milk samples. No practically significant oxidation, however, was detected by the sensory panel. Therefore, the PV and sensory results were sufficient to support our finding that milk from cows fed DDGS up to $25 \%$ DM under these experimental conditions would likely be acceptable to the consumer.

As mentioned previously, feeding of 10 and $25 \%$ DDGS increased long-chain unsaturated FA, $\mathrm{C}_{18: 1}$ and $\mathrm{C}_{18: 2}$, in milk (Table 6). These increases, however, did not cause any increase in PV (all less than $0.5 \mathrm{mEq} / \mathrm{kg}$; data not shown) in any of the milk samples, nor was any practically significant oxidized flavor detected by the trained sensory panel (Tables 7 and 8). A similar situation was observed in a previous study where greater concentrations of $\mathrm{C}_{18: 1}$ in milk did not result in a higher concentration of lipid hydroperoxides, but the elevated concentration of PUFA did (Havemose et al., 2006). In a second study, Liu et al. (2010) observed decreased oxidative stability in milk with increased $\omega-3$ PUFA content. In our study, we did not detect any differences in $\mathrm{C}_{18: 3}$ content in milk from the 3 dietary treatments, 
potentially because $\mathrm{C}_{18: 3}$ and $\mathrm{C}_{20: 0}$ co-eluted. Havemose et al. (2004) reported that milk with lower $\mathrm{C}_{18: 1}$ and $\mathrm{C}_{18: 2}$ but higher $\mathrm{C}_{18: 3}$ had significantly higher content of lipid hydroperoxides. Additionally, the development of SOF in milk has been related to the higher concentration of PUFA in milk fat (Timmons et al., 2001), suggesting that $\mathrm{C}_{18: 3}$ content could possibly be an indicator of the oxidative stability in milk. Timmons et al. (2001), however, suggested that PUFA alone is not always sufficient to promote the development of SOF in milk, which supported the results in the present study and those of Fearon et al. (2004).

Thermal treatment of milk may possibly increase the antioxidant capacity in milk because of protein unfolding and exposure of thiol groups (Taylor and Richardson, 1980; Tong et al., 2000). Heat pasteurization could be one of the factors explaining why no practically significant oxidation was found either by the trained sensory panel or by chemical analyses. Milk samples were pasteurized within $4 \mathrm{~h}$ after collection from the farm, which is shorter than common industry practice. Milk lipid oxidation is a complicated process, because FA composition and antioxidants are only 2 aspects of the many factors that could influence milk oxidative stability. Pro-oxidative factors also can affect to the oxidative stability of milk (e.g., riboflavin). Clearly, lipid oxidation in milk is a complex interplay of prooxidants and antioxidants (Lindmark-Månsson and Åkesson, 2000); the balance between pro-oxidants and antioxidants is a critical factor for the oxidative stability of milk (Stapelfeldt et al., 1999; Sol Morales et al., 2000). Granelli et al. (1998) related the development of SOF in milk with the ratios between antioxidants and PUFA and found that milk samples without SOF tended to have higher antioxidant-to-PUFA ratios than the milk samples with SOF (Granelli et al., 1998). Genetics of cows has been mentioned as an influence on the occurrence of SOF in milk (Juhlin et al., 2010b). Additionally, Juhlin et al. (2010a) found that copper ion concentration in milk from first-lactation cows (1 to 3 wk postpartum) was significantly linked to development of SOF. In our study, we used both primiparous and multiparous mid-lactation dairy cows; thus, no direct comparison can be made. Clearly, several factors have been implicated in the development of SOF in milk; so, the cause is likely not a simple one but rather a multifaceted problem.

The DDGS used in our study was not responsible for SOF in milk. Additionally, because our cows were midlactation and were primiparous and multiparous rather than fresh first-lactation cows, we cannot discount SOF that may appear if this experiment was repeated by using first-lactation transition cows, which produce milk with more copper ions (Juhlin et al., 2010a). Future studies, however, would need to be done to address the question of the occurrence of SOF in early lactation.

\section{CONCLUSIONS}

Feeding 10 and 25\% DDGS (DM basis) in a TMR to lactating dairy cows resulted in significant milk fat depression and a concomitant increase of SNF and protein content of milk. Milk FA profile was altered by dietary inclusion of DDGS. As expected, $\mathrm{C}_{18: 0}$ and long-chain unsaturated FA $\left(\mathrm{C}_{18: 1}\right.$ and $\left.\mathrm{C}_{18: 2}\right)$ increased in milk from cows fed DDGS diets. Ruminal SCFA were not affected by treatment, with the exception of butyrate and isovalerate. A trained sensory panel did detect statistically significant off-flavors in milk from cows fed DDGS, but the low intensity of those defects was of little practical significance. Very low peroxide values from assayed milk supported the results reported by our trained sensory panel. Because no apparent oxidation was detected in milk from cows fed DDGS, the explanation for spontaneous oxidation and SOF is still unclear. Based on our experimental conditions and DDGS source, DDGS does not cause development of SOF in milk.

\section{ACKNOWLEDGMENTS}

This research was supported generously by the Dairy Research Institute (Rosemont, IL), Midwest Dairy Association (Ankeny, IA), and Agricultural Utilization Research Institute (St. Paul, MN). We are particularly thankful for Cathy Hauck, Sakthi Vijayakumar, Pradeep Narayanan, Jody Lohse, Brittney Fritz, and Babu Chinnasamy (Iowa State University staff, undergraduates, and graduate students), who assisted with animal care, milk collection, milk processing, proximate analysis of milk and feeds, and milk and fatty acid analyses. We appreciate the support of Hui Wang in the Center for Crops Utilization Research pilot plant at Iowa State University for technical assistance, and Hansen's Dairy (Hudson, IA) for milk donated for panelist training.

\section{REFERENCES}

Anderson, J. L., D. J. Schingoethe, K. F. Kalscheur, and A. R. Hippen. 2006. Evaluation of dried and wet distillers grains included at two concentrations in the diets of lactating dairy cows. J. Dairy Sci. 89:3133-3142.

Barrefors, P., K. Granelli, L.-A. Appelqvist, and L. Bjoerck. 1995. Chemical characterization of raw milk samples with and without oxidative off-flavor. J. Dairy Sci. 78:2691-2699.

Baumgard, L. H., J. K. Sangster, and D. E. Bauman. 2001. Milk fat synthesis in dairy cows is progressively reduced by increasing 
supplemental amounts of trans-10,cis-12 conjugated linoleic acid (CLA). J. Nutr. 131:1764-1769.

Bautista-Ortega, J., A. Cortes-Cuevas, E. A. Ellis, and C. A. Ruiz-Feria. 2014. Supplemental L-arginine and vitamins $\mathrm{E}$ and $\mathrm{C}$ preserve xanthine oxidase activity in the lung of broiler chickens grown under hypobaric hypoxia. Poult. Sci. 93:979-988.

Charmley, E., and J. W. G. Nicholson. 1993. Injectable $\alpha$-tocopherol for control of oxidized flavour in milk from dairy cows. Can. J. Anim. Sci. 73:381-392.

Charmley, E., and J. W. G. Nicholson. 1994. Influence of dietary fat source on oxidative stability and fatty acid composition of milk from cows receiving a low or high level of dietary vitamin E. Can. J. Anim. Sci. 74:657-664.

Claeys, W. I., S. Cardoen, G. Daube, J. De Block, K. Dewettinck, K. Dierick, L. De Zutter, A. Huyghebaert, H. Imberechts, P. Thiange, Y. Vandenplas, and L. Herman. 2013. Raw or heated cow milk consumption: Review of risks and benefits. Food Contr. 31:251-262.

Costello, M., and S. Clark. 2009. Preparation of samples for instructing students and staff in dairy products evaluation. Page 573 in The Sensory Evaluation of Dairy Products, 2nd ed. Clark, S., M. Costello, M. A. Drake and F. W. Bodyfelt, ed. Springer, New York, NY

Drewnoski, M. E., P. Doane, and S. L. Hansen. 2014. Ferric citrate decreases ruminal hydrogen sulphide concentrations in feedlot cattle fed diets high in sulphate. Br. J. Nutr. 111:261-269.

Dunkley, W. L., and A. A. Franke. 1967. Evaluating susceptibility of milk to oxidized flavor. J. Dairy Sci. 50:1-9.

Fearon, A. M., C. S. Mayne, J. A. M. Beattie, and D. W. Bruce. 2004. Effect of level of oil inclusion in the diet of dairy cows at pasture on animal performance and milk composition and properties. J. Sci. Food Agric. 84:497-504.

Focant, M., E. Mignolet, M. Marique, F. Clabots, T. Breyne, D. Dalemans, and Y. Larondelle. 1998. The effect of vitamin D supplementation of cow diets containing rapeseed and linseed on the prevention of milk fat oxidation. J. Dairy Sci. 81:1095-1101.

Government of Manitoba, Agriculture, Food and Rural Initiatives, 2008. Troubleshooting oxidized flavour problems in bulk milk Manitoba Agriculture, Food and Rural Initiatives. Accessed Feb. 4, 2015. http://en.engormix.com/MA-dairy-cattle/articles/troubleshooting-oxidized-flavour-problems-t1145/p0.htm.

Granelli, K., P. Barrefors, L. Bjöck, and L.-Å. Appelqvist. 1998. Further studies on lipid composition of bovine milk in relation to spontaneous oxidized flavour. J. Sci. Food Agric. 77:161-171.

Haase, G., and W. L. Dunkley. 1969. Ascorbic acid and copper in linoleate oxidation. II. Ascorbic acid and copper as oxidation catalysts. J. Lipid Res. 10:561-567.

Havemose, M. S., M. R. Weisbjerg, W. L. P. Bredie, and J. H. Nielsen. 2004. Influence of feeding different types of roughage on the oxidative stability of milk. Int. Dairy J. 14:563-570.

Havemose, M. S., M. R. Weisbjerg, W. L. P. Bredie, H. D. Poulsen, and J. H. Nielsen. 2006. Oxidative stability of milk influenced by fatty acids, antioxidants, and copper derived from feed. J. Dairy Sci. 89:1970-1980.

Hedegaard, R. V.. D. Kristensen, J. H. Nielson, M. B. Frøst, H. Østdal, J. E. Hermansen, M. Kröger-Ohlsen, and L. H. Skibsted. 2006. Comparison of descriptive sensory analysis and chemical analysis for oxidative changes in milk. J. Dairy Sci. 89:495-504.

Hoffman, L., and A. Baker. 2010. Market issues and prospects for U.S. distillers' grains supply, use, and price relationships. FDS: Feed Outlook. FDS-10k-01. ERS-USDA. Accessed Mar. 7, 2013. http:// www.ers.usda.gov/media/107533/fds10k01_1_.pdf.

Ikwuegbu, O. A., and J. D. Sutton. 1982. The effect of varying the amount of linseed oil supplementation on rumen metabolism in sheep. Br. J. Nutr. 48:365-375.

Janicek, B. N., P. J. Kononoff, A. M. Gehman, and P. H. Doane. 2008. The effect of feeding dried distillers grains plus solubles on milk production and excretion of urinary purine derivatives. J. Dairy Sci. 91:3544-3553.

Jensen, R. G., A. M. Ferris, and C. J. Lammi-Keefe. 1991. The composition of milk fat. J. Dairy Sci. 74:3228-3243.
Juhlin, J., F. Fikse, A. Lunden, J. Pickova, and S. Agenas. 2010b. Relative impact of $\alpha$-tocopherol, copper and fatty acid composition on the occurrence of oxidized milk flavor. J. Dairy Res. 77:302-309.

Juhlin, J., W. F. Fikse, I. L. Örde-Öström, P. Barrefors, and A. Lunden. 2010a. Factors relating to incidence of spontaneous oxidized flavor and copper in cow's milk. Acta Agric. Scand. Anim. Sci. 60:94-103.

Kalscheur, K. F., A. D. Garcia, D. J. Schingoethe, F. D. Royón, and A. R. Hippen. 2012. Feeding biofuel co-products to dairy cattle. Page 130 in Biofuel coproducts as livestock feed: Opportunities and challenges. Food an Agriculture Organization of the United Nations, Rome, Italy. Accessed Dec. 9, 2014. http://www.fao.org/ docrep/016/i3009e/i3009e.pdf.

Kim, T. S., E. A. Decker, and J. H. Lee. 2012. Antioxidant capacities of $\alpha$-tocopherol, trolox, ascorbic acid, and ascorbyl palmitate in riboflavin photosensized oil-in-water emulsions. J. Food Chem. 133:68-75

Kleinschmit, D. H., D. J. Schingoethe, A. R. Hippen, and K. F Kalscheur. 2007. Dried distillers grains plus solubles with corn silage or alfalfa hay as the primary forage source in dairy cow diets. J. Dairy Sci. 90:5587-5599

Leonardi, C., S. Bertice, and L. E. Armentano. 2005. Effect of increasing oil from distillers grains or corn oil on lactation performance. J. Dairy Sci. 88:2820-2827.

Let, M. B., C. Jacobsen, and A. S. Meyer. 2005. Sensory stability and oxidation of fish oil enriched milk is affected by milk storage temperature and oil quality. Int. Dairy J. 15:173-182.

Lin, H., D. Boylston, M. J. Chang, L. O. Luedecke, and T. D. Shultz. 1995. Survey of the conjugated linoleic acid contents of dairy products. J. Dairy Sci. 78:2358-2365.

Lindmark-Månsson, H., and B. Åkesson. 2000. Antioxidative factors in milk. Br. J. Nutr. 84:S103-S110.

Liu, Q., J. Wang, D. Bu, Khas-Erdene, K. Liu, H. Wei, L. Zhou, and D. C. Beitz. 2010. Influence of linoleic acid content on the oxidation of milk fat. J. Agric. Food Chem. 58:3741-3746.

Mann, G. R., S. E. Duncan, K. F. Knowlton, A. D. Dietrich, and S. F. O'Keefe. 2013. Effects of mineral content of bovine drinking water: Does iron content affect milk quality? J. Dairy Sci. 96:7478-7489.

Munyaka, A. W., E. E. Maukule, I. Oey, A. Van Loey, and M. Hendrickx. 2010. Thermal stability of L-ascorbic acid and ascorbic acid oxidase in broccoli (Brassica oleracea var. italica). J. Food Sci. $75: 336-340$.

Nichols, J. R., D. J. Schingoethe, H. A. Maiga, M. J. Brouk, and M. S. Piepenbrink. 1998. Evaluation of corn distillers grains and ruminally protected lysine and methionine for lactating dairy cows. J. Dairy Sci. 81:482-491.

Nicholson, J. W. G., and A. M. St-Laurent. 1991. Effect of forage type and supplemental dietary vitamin E on milk oxidative stability. Can. J. Anim. Sci. 71:1181-1186.

NRC. 2001. Nutrient Requirements of Dairy Cattle. 7th ed. Natl. Acad. Press, Washington, DC.

Offer, N. W., M. Marsden, J. Dixon, B. K. Speake, and F. E. Thacker. 1999. Effect of dietary fat supplements on levels of n-3 polyunsaturated fatty acids, trans acids and conjugated linoleic acid in bovine milk. Anim. Sci. 69:615-625.

Powers, W. J., H. H. Van Horn, B. Harris Jr., and C. J. Wilcox. 1995 Effects of variable sources of distillers dried grains plus solubles on milk yield and composition. J. Dairy Sci. 78:388-396.

Sasikala-Appukuttan, A. K., D. J. Schingoethe, A. R. Hippen, K. F. Kalscheur, K. Karges, and M. L. Gibson. 2008. The feeding value of corn distillers solubles for lactating dairy cows. J. Dairy Sci 91:279-287.

Schingoethe, D. J., M. J. Brouk, and C. P. Birkelo. 1999. Milk production and composition from cows fed wet corn distillers grains. J. Dairy Sci. 82:574-580.

Schingoethe, D. J., K. F. Kalscheur, A. R. Hippen, and A. D. Garcis. 2009. Invited review: The use of distillers products in dairy cattle diets. J. Dairy Sci. 92:5802-5813.

Sol Morales, M., D. L. Palmquist, and W. P. Weiss. 2000. Milk fat composition of Holstein and Jersey cows with control or depleted 
copper status and fed whole soybeans or tallow. J. Dairy Sci. 83:2112-2119.

Stapelfeldt, H., K. N. Nielsen, S. K. Jensen, and L. H. Skibsted. 1999. Free radical formation in freeze-dried raw milk in relation to its $\alpha$-tocopherol level. J. Dairy Sci. 66:461-466.

Sutton, J. D. 1989. Altering milk composition by feeding. J. Dairy Sci. $72: 2801-2814$.

Taylor, M. J., and T. Richardson. 1980. Antioxidant activity of skim milk: Effect of heat and resultant sulfhydryl groups. J. Dairy Sci. 63:1783-1795.

Timmons, J. S., W. P. Weiss, D. L. Palmquist, and W. J. Harper. 2001. Relationships among dietary roasted soybeans, milk components, and spontaneous oxidized flavor milk. J. Dairy Sci. 84:2440-2449.
Tong, L. M., S. Sasaki, D. J. McClements, and E. A. Decker. 2000. Mechanism of antioxidant activity of a high molecular weight fraction of whey. J. Agric. Food Chem. 48:1473-1478.

van Aardt, M., S. E. Duncan, J. E. Marcy, T. E. Long, S. F. O'Keefe, and S. R. Nielsen-Sims. 2005. Effect of antioxidant ( $\alpha$-tocopherol and ascorbic acid) fortification on light-induced flavor of milk. J. Dairy Sci. 88:872-880.

Walstra, P., and R. Jenness. 1984. Dairy Chemistry and Physics. John Wiley \& Sons, Inc., New York, NY.

Zinn, R. A. 1989. Influence of level and source of dietary fat on its comparative feeding value in finishing diets for feedlot steers. J. Anim. Sci. 67:1038-1049. 